\title{
Glucose homeostasis across human airway epithelial cell monolayers: role of diffusion, transport and metabolism
}

\author{
Kameljit K. Kalsi • Emma H. Baker • Owen Fraser • \\ Yuen-Li Chung • Oliver J. Mace • Edward Tarelli • \\ Barbara J. Philips • Deborah L. Baines
}

Received: 1 July 2008 / Accepted: 9 August 2008 /Published online: 10 September 2008

(C) The Author(s) 2008. This article is published with open access at Springerlink.com

\begin{abstract}
Glucose in airway surface liquid (ASL) is maintained at low concentrations compared to blood glucose. Using radiolabelled $\left[{ }^{3} \mathrm{H}\right]$-D-glucose and $\left[{ }^{14} \mathrm{C}\right]-\mathrm{L}-$ glucose, detection of D- and L-glucose by high-performance liquid chromatography and metabolites by nuclear magnetic resonance, we found that glucose applied to the basolateral side of H441 human airway epithelial cell monolayers at a physiological concentration $(5 \mathrm{mM})$ crossed to the apical side by paracellular diffusion. Transepithelial resistance of the monolayer was inversely correlated with paracellular diffusion. Appearance of glucose in the apical compartment was reduced by uptake of glucose into the cell by basolateral and apical phloretin-sensitive GLUT transporters. Glucose taken up into the cell was metabolised to lactate which was then released, at least in part, across the apical membrane. We suggest that glucose transport through GLUT transporters and its subsequent metabolism in lung epithelial cells help to maintain low glucose concentrations in human ASL which is important for protecting the lung against infection.
\end{abstract}

Keywords Glucose - Glucose transport · Epithelium . Airways $\cdot$ Metabolism

\footnotetext{
K. K. Kalsi • E. H. Baker · Y.-L. Chung • O. J. Mace

B. J. Philips $\cdot$ D. L. Baines $(\triangle)$

Centre for Ion Channel and Cell Signalling,

Division of Basic Medical Sciences, St George's,

University of London,

Cranmer Terrace,

London SW17 0RE, UK

e-mail: dbaines@sgul.ac.uk

O. Fraser $\cdot$ E. Tarelli

Biomics Centre, St George's, University of London,

Cranmer Terrace,

London SW17 0RE, UK
}

\section{Introduction}

The epithelium lining the airways forms a resistive barrier that protects the internal milieu from the external environment. The external surface of the epithelium is lined by a thin layer of fluid known as airway surface liquid (ASL). Movement of fluid and solutes between the interstitium and ASL is rigorously controlled by the epithelium. Tight junctions between the epithelial cells restrict passive diffusion of molecules via a paracellular route and appear early in foetal lung development [34]. Transporters, pumps and ion channels located in the apical and basolateral membranes of epithelial cells regulate transepithelial and transcellular flux of ions and molecules [15].

We have previously shown that glucose concentrations in normal ASL are approximately 12.5 times lower than blood glucose concentrations [3]. Our human observations are similar to those in sheep and rat lungs where glucose concentrations were three times to 20 times lower in ASL than in blood $[5,33]$. Low ASL glucose concentrations may play a role in lung defence against infection. In support of this, we found that patients on intensive care with elevated ASL glucose concentrations were more likely to have respiratory infection, particularly with methicillin-resistant Staphylococcus aureus (MRSA), than those with normal ASL glucose concentrations [30].

It is not known how the human airway epithelium regulates the concentration of glucose in ASL, although our observations in human volunteers provide some insight into possible mechanisms. In healthy humans, ASL glucose concentrations rise in response to an experimental increase in blood glucose [3, 40]. This could be explained if glucose moves across the epithelium from interstitium into ASL down its concentration gradient by paracellular diffusion (Fig. 1). In healthy volunteers, when experimental hyper- 
Fig. 1 Representative diagram illustrating the regulation of glucose movement in human airway epithelium. 1 Paracellular passive diffusion of glucose. 2 Glucose uptake by transporters located on the apical and basolateral membranes. 3 Intracellular glucose metabolism

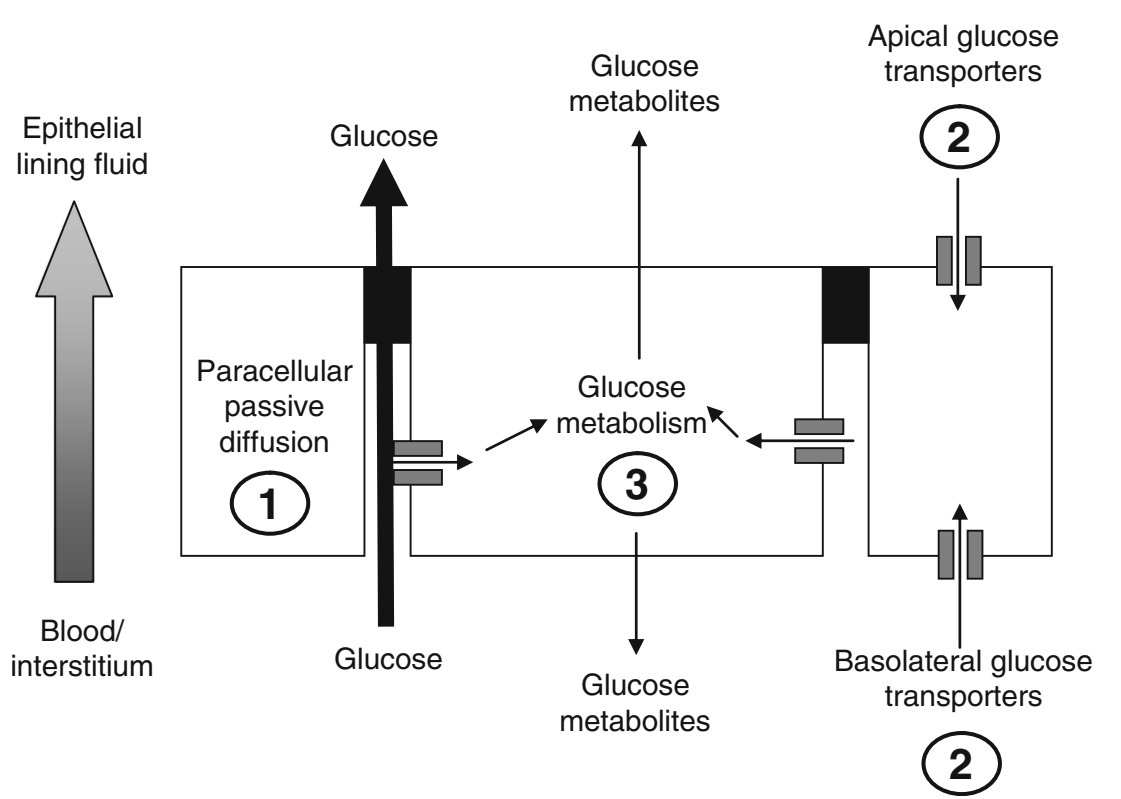

glycaemia is reversed, ASL glucose concentrations fall, but against a transepithelial glucose concentration gradient as ASL glucose always remains lower than blood glucose concentrations [3, 40]. This indicates that glucose is removed from ASL via glucose uptake by epithelial cells. In the distal lungs of rat and sheep, glucose is cleared from the lumen by $\mathrm{Na}^{+} /$glucose co-transport (SGLT) [5, 32]. However, we have shown that glucose transport across the apical and basolateral membranes of polarised human H441 airway epithelial cells utilises GLUT2 transporters (Figs. 1 and 2) [19]. Moreover, GLUT2 protein is also present in the epithelial cells of human bronchiolar biopsies, indicating that GLUT2-mediated transport could be important in human airways. Therefore, metabolism of glucose may also play an important role in clearance of glucose from ASL by regulating the diffusion gradients for glucose uptake and, subsequently, the gradient for paracellular diffusion (Figs. 1, 2 and 3).

In this study and in our previous study [19], we used human H441 cells, which derive from a papillary adenocarcinoma of the bronchiolar epithelium. When cultured at air interface, these cells form an absorptive epithelial monolayer, exhibit vectorial ion transport processes and have similar morphological and phenotypic characteristics to primary cultured human airway epithelial cells (HBEC) and in vivo human airway $[4,8,19]$. Therefore, they have been used by us and a number of other researchers as a model of absorptive human airway epithelium $[25,36,41$, 42]. The aim of this study was to use H441 cell monolayers to explore the process by which glucose diffuses across airway epithelium, to identify the function of GLUT transporters and the role of glucose metabolism in maintaining low glucose concentrations in human ASL.

\section{Materials and methods}

Cell culture

Immortalised human airway epithelial cells (H441) obtained from the American Type Culture Collection (ATCC, Manassas, VA, USA) were cultured in RPMI1640 media containing $10 \%$ foetal calf serum (FCS) (Invitrogen, UK), $10 \mathrm{mM}$ glucose, $2 \mathrm{mM}$ glutamate, $1 \mathrm{mM}$ sodium pyruvate, $10 \mu \mathrm{g} / \mathrm{mL}$ insulin, $5 \mu \mathrm{g} / \mathrm{mL}$ transferrin, $7 \mathrm{ng} / \mathrm{mL}$ sodium selenite, $100 \mathrm{U} / \mathrm{mL}$ penicillin and $100 \mu \mathrm{g} / \mathrm{mL}$ streptomycin. Confluent cultures were trypsinised and polarised by growing on permeable membrane supports (Transwells, Corning, MA, USA) with the basolateral membrane exposed to RPMI media containing $4 \%$ charcoal-stripped serum, $10 \mathrm{mM}$ glucose, $200 \mu \mathrm{M}$

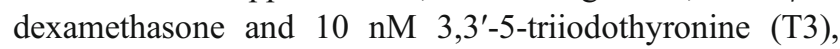
$2 \mathrm{mM}$ L-glutamine, $1 \mathrm{mM}$ sodium pyruvate, $10 \mu \mathrm{g} / \mathrm{mL}$ insulin, $5 \mu \mathrm{g} / \mathrm{mL}$ transferrin, $7 \mathrm{ng} / \mathrm{mL}$ sodium selenite, $100 \mathrm{U} / \mathrm{mL}$ penicillin and $100 \mu \mathrm{g} / \mathrm{mL}$ streptomycin and the apical membrane at air interface for a period of 7-14 days.

\section{Transepithelial glucose flux}

To measure transepithelial glucose flux and transepithelial electrical resistance, confluent monolayers of H441 were mounted in Ussing chambers maintained at $37^{\circ} \mathrm{C}$. Both sides of the epithelial cells were bathed in a physiological salt solution (in millimolars): $\mathrm{NaCl}, 117 ; \mathrm{NaHCO}_{3}, 25$; $\mathrm{KCl}, 4.7 ; \mathrm{MgSO}_{4}, 1.2 ; \mathrm{KH}_{2} \mathrm{PO}_{4}, 1.2 ; \mathrm{CaCl}_{2}, 2.5$ (equilibrated with $5 \% \mathrm{CO}_{2}$ to $\mathrm{pH}$ 7.3-7.4). The solution was bubbled with $21 \% \mathrm{O}_{2}+5 \% \quad \mathrm{CO}_{2}$ pre-mixed gas and continuously circulated throughout the course of the 
A

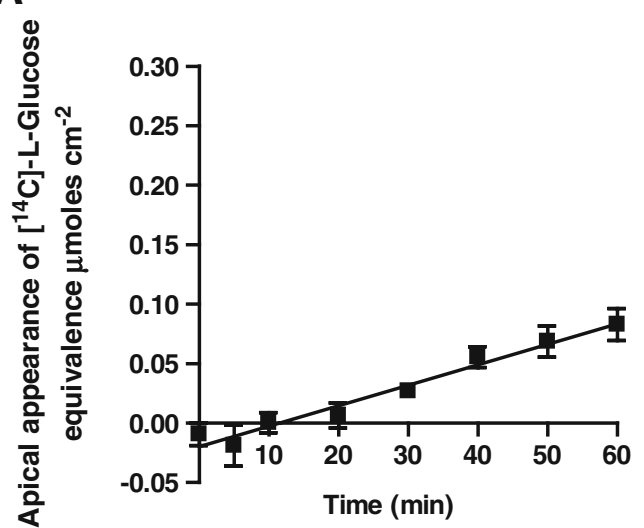

B

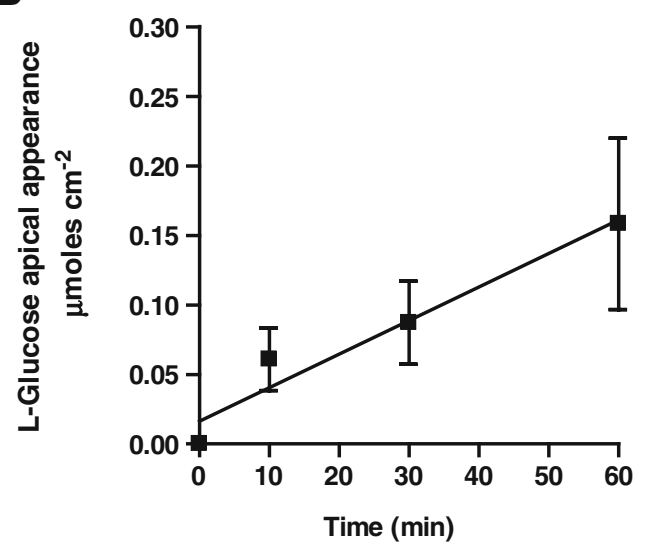

Fig. 2 Time course of apical L-glucose appearance across polarised monolayer of $\mathrm{H} 441$ cells. Cells were incubated with $5 \mathrm{mM}$ L-glucose added to the basolateral reservoir and transport was assessed by sampling the apical reservoir at different intervals for $1 \mathrm{~h}$ of incubation at $37^{\circ} \mathrm{C}$. Transport was traced with $\left[{ }^{14} \mathrm{C}\right]$-L-glucose to assess $\left[{ }^{14} \mathrm{C}\right]$ radiolabel appearance (a) or measured by high-performance anion exchange chromatography with pulsed amperometric detection for Lglucose (b). Data are shown as the mean \pm SEM

experiment. Prior to the experiment, cells were washed then incubated for $20 \mathrm{~min}$ in glucose-free medium.

Transport experiments were initiated by adding $5 \mathrm{mM}$ Dglucose or $5 \mathrm{mM}$ L-glucose (metabolically inert, nontransportable stereoisomer of D-glucose) containing $1.0 \mu \mathrm{Ci}$ of $\left[{ }^{3} \mathrm{H}\right]$-D-glucose or $1.0 \mu \mathrm{Ci}$ of $\left[{ }^{14} \mathrm{C}\right]$-L-glucose, respectively, or $5 \mathrm{mM}$ D-glucose or $5 \mathrm{mM} \mathrm{L}$-glucose alone to the basolateral side of the epithelial cells. After mixing, initial samples of $0.5 \mathrm{~mL}$ were removed immediately from the apical and basolateral baths. In experiments using radiolabel, samples were transferred to scintillation vials to measure the amount of radiolabelled isotope in the incubation solution. In experiments without radiolabel, samples were stored at $4{ }^{\circ} \mathrm{C}$ for measurement of glucose by high-performance liquid chromatography (HPLC). Apical and basolateral samples $(0.5 \mathrm{~mL})$ were taken every $10 \mathrm{~min}$ up to $60 \mathrm{~min}$ for radiolabel and at $0,10,30$ and $60 \mathrm{~min}$ for glucose analysis

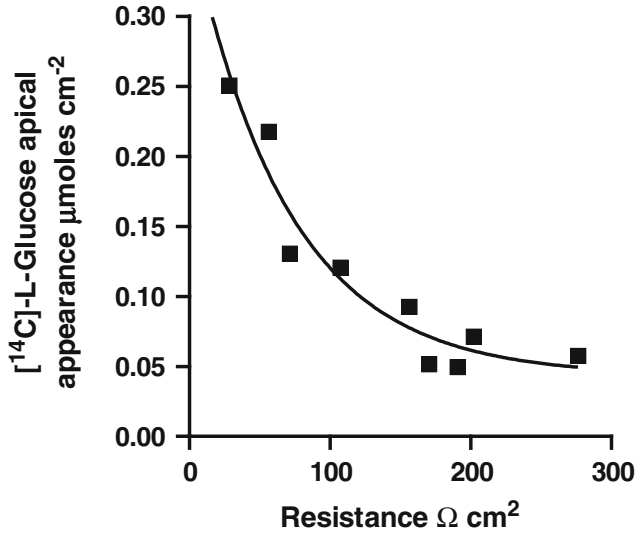

Fig. 3 Relationship between the appearance of $\left[{ }^{14} \mathrm{C}\right]$ radiolabel and resistance of polarised $\mathrm{H} 441$ cells after $60 \mathrm{~min}$ incubation at $37^{\circ} \mathrm{C}$ with $5 \mathrm{mM}$ L-glucose traced with $\left[{ }^{14} \mathrm{C}\right]$-L-glucose

by HPLC. The effect of glucose transport on transepithelial glucose flux was studied using phlorizin $(500 \mu \mathrm{M}$ dissolved in ethanol-an inhibitor of $\mathrm{Na}^{+}$-glucose co-transport, SGLT) or phloretin ( $1 \mathrm{mM}$ dissolved in ethanol-an inhibitor of facilitated glucose transport, GLUT). Inhibitors or vehicle (ethanol) were added to apical or basolateral chambers in the pre-incubation period $(20 \mathrm{~min})$ prior to addition of D- or Lglucose. Appearance of glucose metabolites in the apical chamber when D- or L-glucose was added to the basolateral chamber was measured using a similar protocol. However, samples were only taken for metabolite assay at the start of the experiment and at $60 \mathrm{~min}$. Metabolites in the samples were measured by nuclear magnetic resonance (NMR) as described below.

\section{Transepithelial resistance measurement}

The monolayers were maintained under open circuit conditions whilst the transepithelial potential difference $\left(V_{t}\right)$ was monitored and observed to reach a stable level by using a short-current amplifier (EVC4000 precision V/I clamp; World Precision Instruments). Every $10 \mathrm{~min} V_{\mathrm{t}}$ was then clamped at $0 \mathrm{mV}$ to measure the short-circuit current $\left(I_{\mathrm{sc}}\right)$ so that resistance $\left(R_{\mathrm{t}}\right)$ could be calculated. It was found that the resistance across the monolayers varied between batches of cells, therefore, all controls and treatments were carried out on the same day on monolayers from the same batch.

Analysis of glucose flux using radiolabel

Transepithelial movement of radiolabel from the basolateral to the apical chamber was determined by measuring the amount of tracer radioisotope/glucose as counts per minute (cpm) that had appeared in the apical tracer/glucose-free chamber. Glucose equivalence was calculated using the equation: $(\Delta \mathrm{cpm}$ in the apical chamber/total $\mathrm{cpm}$ in the 
basolateral chamber $\times \Delta$ time $) \times$ concentration of glucose [26].

\section{HPLC analysis of glucose}

Transepithelial movement of glucose across the monolayers was measured as described above. Samples were analysed by high-performance anion exchange chromatography with pulse amperometric detection HPAEC-PAD (Dionex ICS 2500, Dionex, CA, USA) equipped with CarboPac PA20 chromatography column [37]. Chromatographic separation was achieved by using $2.0 \mathrm{mM} \mathrm{NaOH}$ and deionised water $(18.2 \mathrm{M} \Omega / \mathrm{cm})$ at a flow rate of $0.5 \mathrm{~mL} / \mathrm{min}$. Sample peak for glucose was integrated and quantified by using the Chromeleon software (version 6.8; Dionex, CA, USA). Standard glucose solutions were used to set up a calibration curve. Assay sensitivity was $0.01 \mu \mathrm{M}$, and lower limit of glucose detection was $0.001 \mu \mathrm{M}$.

${ }^{1} \mathrm{H}$ NMR analysis of metabolites

Samples from the apical side of the Ussing chamber were collected and freeze-dried. The samples were then reconstituted in $0.6 \mathrm{~mL}$ of $\mathrm{D}_{2} \mathrm{O}$. Sodium 3-trimethylsilyl-2,2,3,3tetradeuteropropionate (TSP; $0.125 \%$ ) was added to the sample for chemical shift calibration and quantification. Proton NMR of the released metabolites was performed on a Bruker $500 \mathrm{MHz}$ NMR system (pulse angle, $90^{\circ} \mathrm{C}$; repetition time, $2 \mathrm{~s}$ ). The water resonance was suppressed by pre-saturation. Metabolite concentrations were determined by integration and normalised relative to the peak integral of the TSP reference.

\section{Statistical analysis}

Values are reported as the mean \pm SEM. Statistical analysis was performed using paired Student's $t$ test or analysis of variance (ANOVA) tests followed by Bonferroni or Newman-Keuls multiple comparison post hoc tests. $P$ values of $<0.05$ were considered statistically significant.

\section{Results}

Paracellular diffusion of glucose

The passive diffusion of glucose across $\mathrm{H} 441$ cell monolayers from the basolateral compartment to the apical compartment was determined using L-glucose, a metabolically inert, non-transportable stereoisomer of D-glucose. Lglucose flux was assessed both by measurement of radiolabelled $\left[{ }^{14} \mathrm{C}\right]$-L-glucose (expressed as $\left[{ }^{14} \mathrm{C}\right]$-L-glucose equivalence, see the "Materials and methods" section) and by HPLC analysis of unlabelled L-glucose. The appearance of $\left[{ }^{14} \mathrm{C}\right]$-L-glucose equivalence (Fig. 2a) and L-glucose (Fig. 2b) increased in a linear manner over $60 \mathrm{~min}$. The rate of appearance of $\left[{ }^{14} \mathrm{C}\right]$-L-glucose equivalence and unlabelled L-glucose was not significantly different at any time points. After $60 \mathrm{~min}$, the amounts of $\left[{ }^{14} \mathrm{C}\right]$-L-glucose equivalence and L-glucose appearing in the apical chamber were similar $\left(0 . \pm 0.013\right.$ and $0.158 \pm 0.062 \mu \mathrm{mol} \mathrm{cm}^{-2}, n=4$, respectively). Since L-glucose is not transported and not metabolised, these data indicate that glucose crosses H441 cell monolayers by paracellular diffusion.

Effect of transepithelial resistance on paracellular diffusion of L-glucose

The amount of L-glucose appearing in the apical chamber at 60 min was plotted against the corresponding transepithelial resistance (TER) values for each monolayer used in this study (Fig. 3). The appearance of L-glucose in the apical chamber correlated with a decrease in TER $\left(R^{2}=-0.933\right.$, $p=0.0021, n=9$ ) with the best fit for data being a one-phase exponential decay curve. According to Pappenheimer et al. [27, 29], glucose diffusion across a membrane is proportional to the radius of pores in that membrane. In our model, L-glucose appears to diffuse paracellularly through pores in the tight junctions between H441 epithelial cells. The increasing appearance of glucose with decreasing TER could indicate an effect of different pore sizes on glucose movement. At TER $>100 \Omega \mathrm{cm}^{2}$ where the appearance of L-glucose did not rise above $0.10 \mu \mathrm{mol}$ $\mathrm{cm}^{-2}$, pore size appears to be small enough to restrict glucose flow. At TER $<100 \Omega \mathrm{cm}^{2}$ where there was a steep rise in the amount of L-glucose appearing in the apical chamber $\left(0.17-0.25 \mu \mathrm{mol} \mathrm{cm} \mathrm{cm}^{-2}\right)$, pore size appears to be larger and less restrictive to glucose flow.

Because of the importance of TER to passive movement of L-glucose across the monolayer, we measured TER values in our control, vehicle and treatment groups (Table 1). We also compared whether TER values were different with D-glucose and the treatment groups. There was no change in TER between 0 and $60 \mathrm{~min}$ in control monolayers or vehicle-treated monolayers with L- or Dglucose. There were significant changes in TER after $60 \mathrm{~min}$ apical application of phloretin (PT) (GLUT inhibitor) in the presence of either L- or D-glucose $(p<$ $0.01, n=5$ compared to TER values at the start of the experiment).

As TER is an important determinant of apical appearance of glucose, this affected the permeability coefficients $\left(P_{\text {app }}\right)$ for L-glucose in our treatment groups (Table 2). Calculation of the permeability coefficients were performed using the following equation: $P_{\text {app }}=\left(1 /\left(A \times C_{\mathrm{o}}\right) \times\right.$ $(\Delta Q / \Delta t))$ where $A$ is the surface area of the filter 
Table 1 Changes in TER measured in a monolayer of H441 cells in control, ethanol (vehicle control), in the presence of $500 \mu \mathrm{M} \mathrm{PZ}$ and $1 \mathrm{mM}$ PT applied to the apical (APT) or basolateral (BPT) membrane

\begin{tabular}{|c|c|c|c|c|}
\hline & \multicolumn{2}{|c|}{$\begin{array}{l}\text { L-glucose } \\
\text { (resistance, } \Omega \mathrm{cm}^{2} \text { ) }\end{array}$} & \multicolumn{2}{|c|}{$\begin{array}{l}\text { D-glucose } \\
\text { (resistance, } \Omega \mathrm{cm}^{2} \text { ) }\end{array}$} \\
\hline & Start & End & Start & End \\
\hline Control & $238.6 \pm 25.3$ & $222.8 \pm 35.0$ & $177.1 \pm 40.1$ & $166.0 \pm 45.1$ \\
\hline $\begin{array}{l}\text { Ethanol } \\
\text { (vehicle) }\end{array}$ & $140.8 \pm 35.9$ & $166.1 \pm 45.1$ & $255.3 \pm 25.2$ & $227.1 \pm 8.6$ \\
\hline $\mathrm{PZ}$ & $146.9 \pm 45.2$ & $46.7 \pm 13.3$ & $127.2 \pm 37.1$ & $59.2 \pm 8.8$ \\
\hline APT & $103.1 \pm 9.1$ & $30.6 \pm 3.0 * *$ & $104.3 \pm 13.2$ & $38.9 \pm 6.4 * *$ \\
\hline BPT & $148.3 \pm 30.4$ & $44.4 \pm 8.0$ & $165.8 \pm 33.3$ & $80.0 \pm 20.1$ \\
\hline
\end{tabular}

Values are presented as the means \pm SEM and $n=3-6$

${ }^{* *} p<0.01$, resistance measured at the start compared to the resistance after $60 \mathrm{~min}$

$\left(0.98 \mathrm{~cm}^{2}\right), C_{\mathrm{o}}$ is the initial concentration of glucose in the donor fluid and $Q$ is the amount of glucose passing into the receiver compartment. The paracellular permeability of Lglucose was similar in control and in ethanol (vehicle)treated monolayers. Consistent with the lower TER in the presence of PT, $P_{\text {app }}$ values were higher than control or vehicle (Table 2). These data indicate that the glucose transport inhibitors modulate resistance and permeability of H441 cell monolayers to glucose. To control for changes in permeability in experiments investigating D-glucose flux, we subsequently used both D- and L-glucose in all experiments and expressed D-glucose results as D-glucose minus the non-metabolised paracellular component assessed by Lglucose.

Apical appearance of $\left[{ }^{3} \mathrm{H}\right]$-D-glucose equivalence

Apical appearance of $5 \mathrm{mM}$ basolaterally applied Dglucose was traced by $\left[{ }^{3} \mathrm{H}\right]$-D-glucose. The D-glucose$\left[{ }^{3} \mathrm{H}\right]$-equivalence (less the non-metabolised paracellular component assessed by $\left[{ }^{14} \mathrm{C}\right]$-L-glucose, see above) was calculated as outlined in the "Materials and methods" section (Fig. 4a). In control non-treated cells, over a time course of

Table $2 P_{\text {app }}$ values for the transport of L-glucose across a monolayer of H441 cells in control, ethanol (vehicle control), in the presence of $1 \mathrm{mM}$ PT or $500 \mu \mathrm{M} \mathrm{PZ}$

\begin{tabular}{lc}
\hline & $P_{\text {app }}\left(\times 10^{-6} \mathrm{~cm} / \mathrm{s}\right)$ L-glucose \\
\hline Control & $5.2 \pm 0.5$ \\
Ethanol (vehicle) & $5.9 \pm 0.7$ \\
PT & $12.4 \pm 3.3$ \\
PZ & $9.9 \pm 3.2$ \\
\hline
\end{tabular}

Values are presented as the means $\pm \operatorname{SEM}(n=3-6)$
$60 \mathrm{~min},\left[{ }^{3} \mathrm{H}\right]$ appearance in the apical compartment was in a linear fashion. At $60 \mathrm{~min}$, the calculated D-glucose equivalence that appeared in the apical chamber (minus L-glucose) was $0.06 \pm 0.01 \mu \mathrm{mol} \mathrm{cm}{ }^{-2}$ (Fig. $4 \mathrm{a}$ and b).

In the presence of the GLUT transport inhibitor phloretin (PT) applied to the basolateral chamber, the appearance of $\left[{ }^{3} \mathrm{H}\right]$ radiolabel and D-glucose equivalence (minus L-glucose) in the apical bath at $60 \mathrm{~min}$ was significantly reduced $(-0.01$ $\left.\pm 0.01 \mu \mathrm{mol} \mathrm{cm}{ }^{-2}, p<0.05, n=3\right)$ compared to control. The negative value obtained also indicated that less D-glucose equivalence appeared in the apical chamber than L-glucose (Fig. 4b). The appearance of $\left[{ }^{3} \mathrm{H}\right]$-D-glucose equivalence (minus L-glucose) in the presence of the SGLT inhibitor phlorizin (PZ) was not significantly different to control $\left(0.03 \pm 0.01 \mu \mathrm{mol} \mathrm{cm} \mathrm{cm}^{-2}, n=3\right)$. These data could be
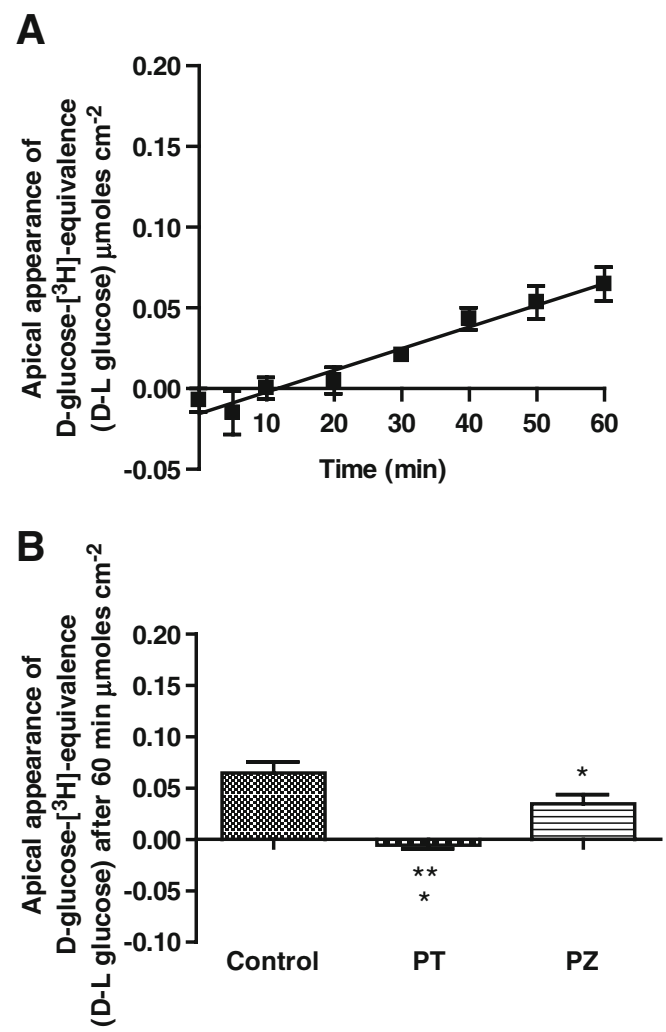

Fig. 4 Time course and basolateral inhibition of apical appearance of $\left[{ }^{3} \mathrm{H}\right]$-D-glucose equivalence across polarised monolayer of $\mathrm{H} 441$ cells. Cells were incubated with $5 \mathrm{mM}$ D-glucose traced with $\left[{ }^{3} \mathrm{H}\right]$-D-glucose added to the basolateral reservoir. Transport was assessed by sampling the apical reservoir for $\left[{ }^{3} \mathrm{H}\right]$ at different intervals for $1 \mathrm{~h}$ of incubation at $37^{\circ} \mathrm{C}$ (a). Inhibitors were added to the basolateral reservoir and preincubated for $20 \mathrm{~min}$. Cells were treated with vehicle (control), $1 \mathrm{mM}$ phloretin $(P T)$ or $500 \mu \mathrm{M}$ phlorizin $(P Z)$ prior to the addition of $5 \mathrm{mM}$ D-glucose traced with $\left[{ }^{3} \mathrm{H}\right]$-D-glucose. Apical $\left[{ }^{3} \mathrm{H}\right]$ was measured after $60 \mathrm{~min}$ of incubation at $37^{\circ} \mathrm{C}$ (b). L-glucose controls were performed for all experiments and values are expressed as D-glucose minus Lglucose to control for effect of varying transepithelial resistance on permeability. Data are shown as the mean \pm SEM. ${ }^{* *} p<0.01$, significantly different from control; ${ }^{*} p<0.05$, significantly different from $\mathrm{PZ}$ and control 
explained if basolateral PT-sensitive GLUT transporters are involved in the uptake of D-glucose and the appearance of ${ }^{3} \mathrm{H}$ (and thus D-glucose equivalence) in the apical chamber. Consistent with previous observations [19], there was no basolateral PZ-sensitive SGLT-mediated transport.

\section{Apical appearance of D-glucose}

After basolateral application of $5 \mathrm{mM}$ D-glucose, the appearance of D-glucose in the apical chamber (less Lglucose) was calculated. There was a negative linear correlation in apical appearance of D-glucose relative to Lglucose over $60 \mathrm{~min}$ (Fig. 5a). In control monolayers after $60 \mathrm{~min}$, the appearance of D-glucose relative to L-glucose was $-0.14 \pm 0.01 \mu \mathrm{mol} \mathrm{cm} \mathrm{cm}^{-2}$ (Fig. 5a and b). In contrast to the data obtained by calculation of $\left[{ }^{3} \mathrm{H}\right]$-D-glucose equivalence, these data indicate that less D-glucose than Lglucose appears in the apical chamber, raising the possibility that D-glucose is transported into the lung cell and metabolised.

Application of PT to the basolateral bath significantly increased D-glucose appearance relative to L-glucose appearance compared to control $\left(-0.02 \pm 0.01 \mu \mathrm{mol} \mathrm{cm}{ }^{-2}\right.$, $p<0.05, n=5$ ), although values remained negative. Application of PT to the apical chamber resulted in a significantly greater apical appearance of D-glucose (less L-glucose) at $60 \mathrm{~min}$ compared to control $\left(0.07 \pm 0.05 \mu \mathrm{mol} \mathrm{cm} \mathrm{cm}^{-2}\right.$, $p<0.01, n=5)$. Overall, these results indicate that glucose uptake via basolateral and apical GLUT transporters in H441 cell monolayers modulate apical D-glucose appearance.

\section{Apical release of metabolites}

Because we found that ${ }^{3} \mathrm{H}$ but not D-glucose appeared in the apical compartment, we investigated whether apical radiolabel appearance was associated with a product of Dglucose metabolism. Metabolite appearance after the basolateral addition of $5 \mathrm{mM}$ D-glucose or $5 \mathrm{mM}$ L-glucose were analysed at $60 \mathrm{~min}$ by proton NMR.

The major metabolites detectable in the apical chamber were lactate and, to a lesser extent, acetate. The NMR signal for other metabolites such as alanine, dimethylamine and glycine were very weak or were undetectable. To correct for the release of metabolites from other sources, the amount of lactate and acetate detected after the addition of D-glucose minus the amount detected after the addition of L-glucose (which is not metabolised) is presented. In control monolayers, lactate appearance for Dglucose relative to L-glucose was $0.116 \pm 0.039 \mu \mathrm{mol} \mathrm{cm}{ }^{-2}$ after $60 \mathrm{~min}$. Basolateral and apical addition of PT reduced lactate appearance for $\mathrm{D}$-glucose relative to $\mathrm{L}$-glucose to $-0.016 \pm 0.022$ and $0.015 \pm 0.025 \mu \mathrm{mol} \mathrm{cm}{ }^{-2}$, respectively, $p=0.05, n=3$ (Fig. 6a).
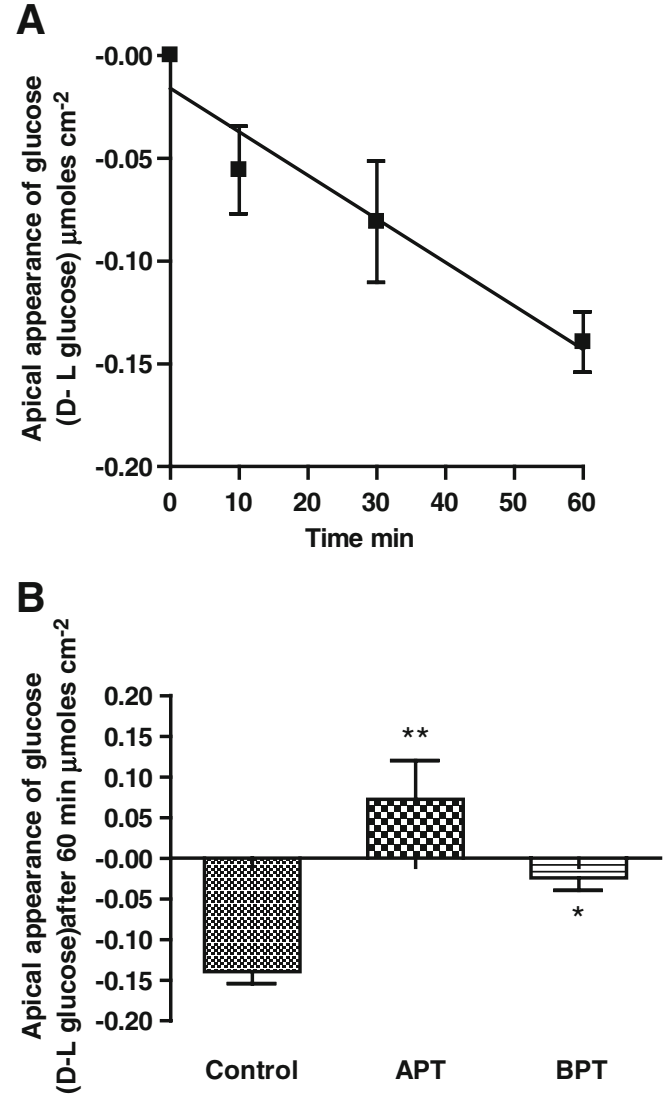

Fig. 5 Time course and inhibition of apical appearance of glucose across polarised monolayer of $\mathrm{H} 441$ cells. Cells were incubated with $5 \mathrm{mM}$ Dglucose added to the basolateral reservoir, apical appearance was assessed by sampling the apical reservoir for glucose at different intervals for $1 \mathrm{~h}$ of incubation at $37^{\circ} \mathrm{C}$ (a). Pre-treatment with $1 \mathrm{mM}$ phloretin added to either the apical $(A P T)$ or the basolateral $(B P T)$ reservoir was compared to vehicle (control) prior to the addition of $5 \mathrm{mM}$ D-glucose. Glucose appearance was measured after $60 \mathrm{~min}$ incubation at $37^{\circ} \mathrm{C}$. L-glucose controls were performed for all experiments and values are expressed as D-glucose minus L-glucose to control for the effect of varying transepithelial resistance on permeability. Data are shown as the mean \pm SEM. ${ }^{*} p<0.05$, significantly different from control; ** $p<0.01$, significantly different from control

In control monolayers, acetate appearance for Dglucose relative to L-glucose was $0.004 \pm 0.002 \mu \mathrm{mol}$ $\mathrm{cm}^{-2}$ (Fig. 6b). Addition of PT to either the basolateral or apical membrane did not significantly change apical acetate appearance $\left(0.019 \pm 0.015 \mu \mathrm{mol} \mathrm{cm} \mathrm{cm}^{-2}\right.$ with apical PT and $-0.008 \pm 0.011 \mu \mathrm{mol} \mathrm{cm}{ }^{-2}$ with basolateral PT).

These data indicate that D-glucose taken up by the cell is rapidly metabolised to lactate, which is released (at least in part) into the apical compartment.

\section{Discussion}

We have investigated the contribution of paracellular diffusion, glucose transport and glucose metabolism to 

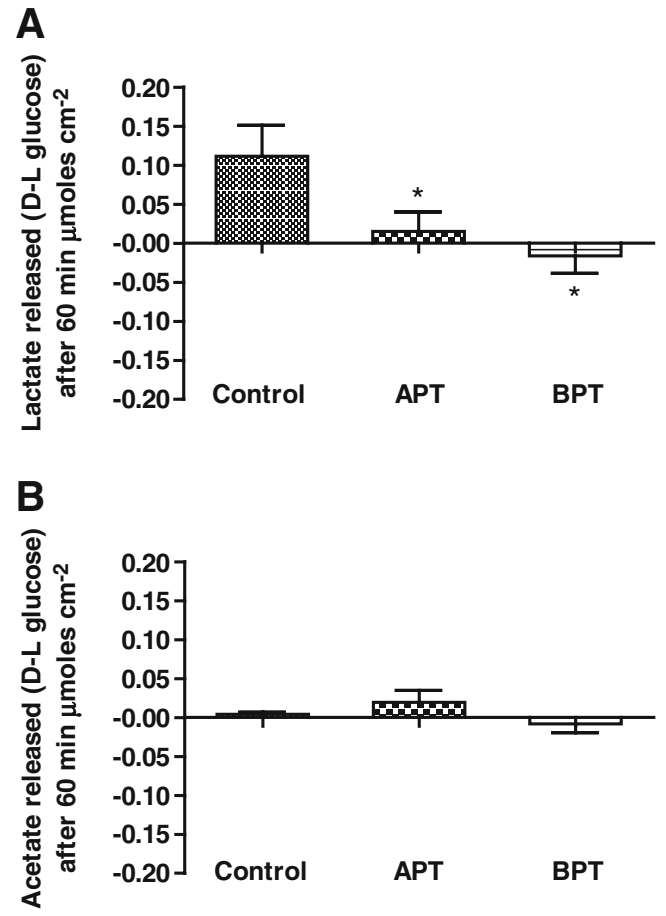

Fig. 6 Apical appearance of lactate and acetate analysed by ${ }^{1} \mathrm{H}$ NMR. Cells were pre-incubated with vehicle (control) or with $1 \mathrm{mM}$ phloretin $(P T)$ added to either the apical $(A P T)$ or the basolateral $(B P T)$ reservoir prior to the addition of $5 \mathrm{mM}$ D-glucose to the basolateral reservoir. The apical reservoir was sampled for lactate (a) and acetate (b) after $1 \mathrm{~h}$ of incubation at $37^{\circ} \mathrm{C}$. L-glucose controls were performed for all experiments and values are expressed as Dglucose minus L-glucose to control for effect of varying transepithelial resistance on permeability. Data are shown as the mean \pm SEM. ${ }^{*} p<$ 0.05 , significantly different from control

glucose homeostasis across polarised monolayers of H441 epithelial cells.

Paracellular diffusion of L-glucose

We found that when a physiological concentration $(5 \mathrm{mM})$ of unlabelled L-glucose or $\left[{ }^{14} \mathrm{C}\right]$-L-glucose was added to the basolateral side of the monolayer, L-glucose appeared in the apical chamber and the concentration increased over time. These observations are consistent with the findings that rabbit respiratory epithelium and sheep alveolar epithelium were also permeable to L-glucose [5, 38]. As L-glucose is a non-transportable, non-metabolisable stereoisomer of Dglucose, movement of L-glucose from one side of the cell monolayer to the other must be by passive processes such as paracellular diffusion.

We observed that the appearance of L-glucose was strongly affected by the resistance of the H441 monolayer so that more L-glucose appeared in the apical bath when the resistance was decreased. Paracellular diffusion is limited by the permeability and selectivity of the tight junctions between the epithelial cells [1]. As the electrical resistance of monolayers is determined by the permeability of the tight junctions to ions, then a lower TER indicates an increased permeability to solutes [12]. Consistent with this concept, we found that the calculated permeability coefficient $\left(P_{\text {app }}\right)$ for L-glucose was similar to that reported for sodium fluorescein $\left(3.65 \pm 0.56 \times 10^{-6} \mathrm{~cm} / \mathrm{s}\right)$ across $\mathrm{H} 441$ cell monolayers [18]. Furthermore, both values for $P_{\text {app }}$ across H441 monolayers were higher than that described for mannitol (which is of similar size to glucose) across colonic epithelial (Caco2) cell monolayers $\left(0.43 \pm 0.05 \times 10^{-6} \mathrm{~cm} / \mathrm{s}\right)$ which have a correspondingly higher TER (approximately $1,500 \Omega \mathrm{cm}^{2}$ ) [12]. Thus, H441 cell monolayers are relatively leaky to glucose consistent with their lower TER. Interestingly, TER exhibited by H441 cells is reported to be similar to airway TER in vivo [9]. Therefore, the in vitro data presented in this study support the notion that the human airway is relatively leaky to glucose. They also support our previous observations in vivo that glucose rapidly diffuses across the epithelium into ASL when blood glucose is raised in human subjects $[3,40]$.

We found that the relationship between TER and glucose appearance in the apical chamber was not linear but followed a one-phase exponential decay curve. As TER decreased, there was an exponential increase in glucose appearance in the apical chamber. These new data indicate that a reduction in epithelial resistance in vivo (e.g. by inflammation) could lead to an increased glucose leak into the airspace. Certainly, animal studies indicate that increasing paracellular permeability with protamine in fluid-filled isolated rat lungs increased glucose concentration in the instilled fluid [32]. We have shown that patients with lung inflammation due to cystic fibrosis have elevated ASL glucose concentrations $(2.0 \pm 1.1 \mathrm{mM}$, control $0.4 \pm 0.2 \mathrm{mM})$ and ASL glucose only three to four times lower (cf. 12.5 times lower) than blood glucose. Increased pulmonary epithelial permeability has been demonstrated in cystic fibrosis patients as increased ${ }^{99 \mathrm{~m}}$ Tc-labelled diethylene triamine pentaacetic acid uptake [11] and using in vitro techniques [10] and could contribute to elevated ASL glucose concentrations in these patients.

Interestingly, the glucose transport inhibitors phloretin and phlorizin decreased TER and increased $P_{\text {app }}$ but Lglucose had no effect on TER. We do not yet have an explanation for these findings. However, these data indicate that the glucose transport inhibitors modulate resistance and permeability of H441 cell monolayers to glucose. To control for changes in permeability in experiments investigating D-glucose flux, we, therefore, used both D- and L-glucose in all subsequent experiments and expressed Dglucose results as D-glucose minus the non-metabolised paracellular component assessed by L-glucose. 
Factors regulating apical appearance of D-glucose

When measured by HPLC, apical D-glucose appearance was less than L-glucose appearance. As passive movement of D- and L-glucose should be the same, differences in apical appearance of the stereoisomers must be due to transport and/or metabolism of D-glucose.

\section{Transport}

We have previously shown that GLUT2 transporters are present in the apical and basolateral membranes of H441 cells and human bronchial biopsies and that the GLUT inhibitor phloretin inhibited glucose uptake by these cells [19]. In the present study, we found that phloretin applied either basolaterally or apically increased the appearance of D-glucose in the apical compartment. When phloretin was applied to the basolateral side of the membrane, D-glucose appearance in the apical chamber became similar to values obtained for passive diffusion of L-glucose. One explanation for this could be that transport of D-glucose into the cell across the basolateral/lateral membranes reduces the gradient for D-glucose diffusion via the paracellular pathway. In the face of such a large transepithelial gradient for glucose, it is difficult to identify a mechanism to accommodate such findings. However, we previously showed that there is substantial GLUT-mediated transport across the basolateral membrane of H441 cells [19]. It is, therefore, possible that basolateral D-glucose uptake reduces the amount of glucose that moves between the monolayer of cells and the porous filter and/or passively between the cells. We propose that this could alter the glucose concentration in the basolateral/lateral microenvi- ronment and, consequently, the transepithelial diffusion gradient (see Fig. 7). Apical inhibition of GLUT transport also resulted in increased glucose appearance. H441 cell monolayers exhibit apical GLUT2-mediated transport. Thus, uptake of D-glucose from the apical chamber into the cell via GLUT2 in the apical membrane could also reduce the amount of D-glucose in the apical chamber (see Fig. 7). This process would require glucose to be rapidly metabolised once entering the lung epithelial cell to maintain a diffusion gradient for glucose entry across the apical membrane. This proposed mechanism contrasts to that of the gut where the transepithelial glucose gradient is in the opposite direction. Luminal glucose is much higher than blood glucose (range between 16 and $300 \mathrm{mM}$ ) [16, $28]$ and the majority of glucose is transported from the lumen into the circulation down the concentration gradient without entering the Kreb's cycle for metabolism.

H441 cells require treatment with high-dose glucocorticoids to exhibit a phenotype resembling a classical surface epithelial cell. In our study, once H441 cells reached confluence, they were cultured with $200 \mu \mathrm{M}$ dexamethasone at air interface for 7-14 days. In a number of tissues, culture with glucocorticoids inhibits apical expression of GLUT2 [35] and this could account for our previous observation that phloretin-sensitive glucose uptake was less across apical than basolateral membranes [19]. In the present study, despite possible inhibition of apical GLUT2 expression, we were still able to demonstrate an effect of phloretin on apical glucose appearance and this is consistent with our observations in human bronchial mucosal biopsies that GLUT2 is expressed in both apical and basolateral membranes of human airway epithelial cells [19].
Fig. 7 Proposed mechanism of paracellular diffusion, flux and metabolism of glucose in lung epithelial cells

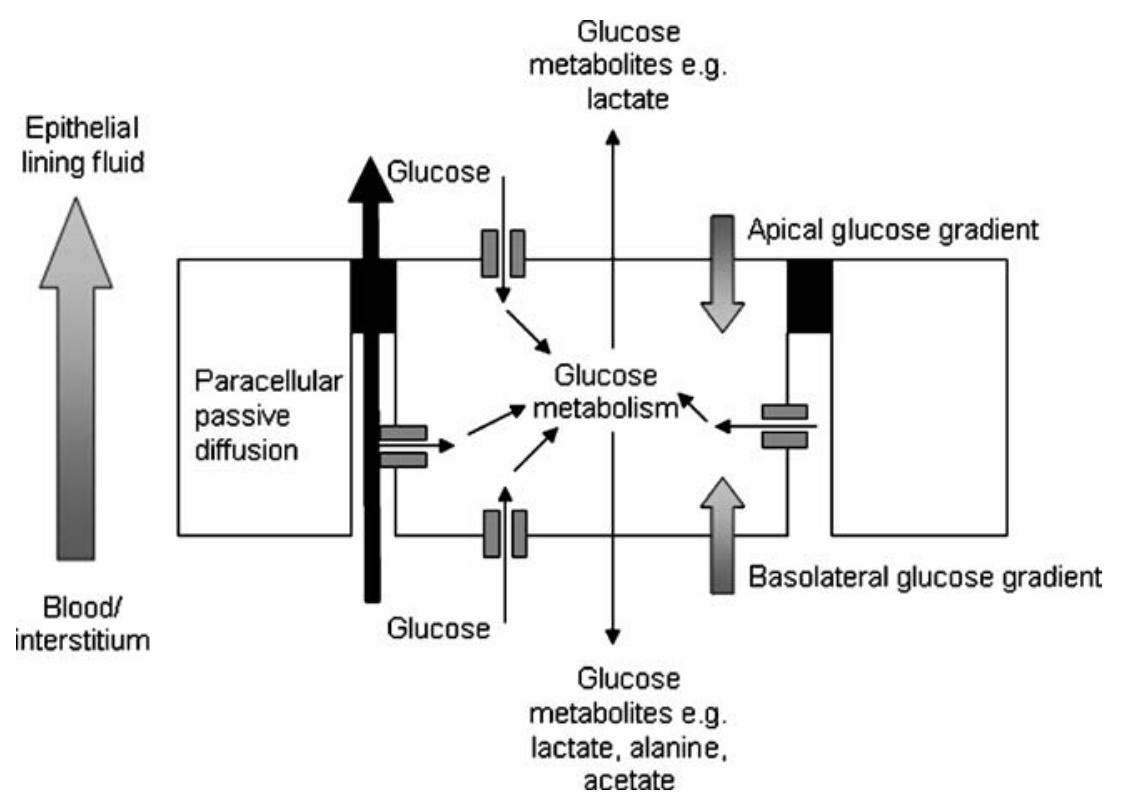




\section{Metabolism}

Although HPLC measurements did not demonstrate increased appearance of apical D-glucose relative to L-glucose, radiolabel studies demonstrated increased $\left[{ }^{3} \mathrm{H}\right]$-D-glucose equivalence appearing in the apical chamber compared to $\left[{ }^{14} \mathrm{C}\right]$-L-glucose equivalence. This raised the possibility that $\left[{ }^{3} \mathrm{H}\right]$-D-glucose was being taken up by $\mathrm{H} 441$ cells and metabolised and the ${ }^{3} \mathrm{H}$ moiety found in the apical chamber was associated with a glucose metabolite. Previous studies have shown that the $\left[{ }^{3} \mathrm{H}\right]$ on glucose is usually irreversibly lost as water or is incorporated into other molecules [20, 31]. Once D-glucose is transported into the cell, evidence in rat lungs indicated that it was metabolised immediately by hexokinase to glucose-6-phosphate, which then entered the glycolytic pathway to produce lactate and pyruvate $[6,7$, 38].

In our model, we found, using NMR spectroscopy, that concentrations of the glucose metabolites lactate (and, to a lesser extent, acetate) were elevated in the apical chamber after $60 \mathrm{~min}$ of incubation with D-glucose, but not Lglucose. Basolateral phloretin inhibited the appearance of $\left[{ }^{3} \mathrm{H}\right]$ in the apical reservoir and both apical and basolateral phloretin attenuated lactate release into the apical compartment. It is possible that these findings could be explained by an inhibitory effect of phloretin on glucose metabolism [2]. However, phlorizin, which also can inhibit glucose metabolism at concentrations used in this study [21], did not alter apical $\left[{ }^{3} \mathrm{H}\right]$. An alternative explanation is that glucose is taken up through phloretin-blockable GLUT transporters into H441 cells where it is rapidly metabolised to lactate, which is then released from the cell. This process, consistent with behaviour of retinal epithelial cells [39], would aid the generation and maintenance of the transmembrane gradient for glucose uptake, supporting clearance of glucose from ASL by apical GLUT transporters. Interestingly, our data contrast with those of Saumon and co-workers who found that lung glucose uptake in isolated perfused rat lungs was not inhibited by phloretin or glucose metabolism. However, glucose transport in this study was predominantly by SGLT whereas in human airway GLUT transport prevails. It is possible that the difference between the two studies could indicate regional and species differences in transporter expression $[19,33]$.

The mechanisms whereby lactate and acetate are released from the cell into the apical compartment in H441 cells are as yet unknown. The transport of monocarboxylates such as lactate and pyruvate is usually either by co-transport with protons or by exchange with another monocarboxylate via monocarboxylate transporters (MCTs) [13]. In human lung cancers, the presence of monocarboxylate transporter-1 (MCT1) is implicated in lactate extru- sion [23, 24]. Transport of monocarboxylates can be inhibited competitively by other monocarboxylates or by bioflavonoids such as quercetin and phloretin. Interestingly, phloretin inhibits MCTs with similar efficacy to the inhibition of GLUTs $[14,17]$. This raises the possibility in our model that phloretin inhibited lactate transport out of H441 cells as well as inhibiting glucose uptake. Transport of acetate may also be mediated by MCT1 as proposed by an in vivo and in vitro study in the goat gastrointestinal tract [22]. In our study, acetate appearance in the apical reservoir was unaffected by the presence of phloretin, which could indicate the presence of phloretin-insensitive transporters. Alternatively, as acetate levels were very low, it is likely that small changes in the presence of phloretin were not detected by proton NMR.

In conclusion, using radiolabelled glucose, detection of glucose by HPLC and measurement of glucose metabolites by NMR, we have identified that glucose moves across H441 lung epithelial cell monolayers by basolateral to apical paracellular diffusion. However, the resultant appearance of glucose in the apical compartment is reduced by uptake of glucose into the cell by basolateral and apical GLUT transporters, most likely GLUT2. Glucose taken up into the cell is metabolised to lactate which is then released, at least in part, across the apical membrane. We propose a working model for glucose flux across human airway epithelial cells as illustrated in Fig. 7. We suggest that the mechanisms outlined in this model help to maintain the low glucose concentration in human ASL which is important for protecting the lung against infection. Elevated ASL glucose concentrations in patients with lung inflammation could be the result of changes in epithelial permeability, epithelial glucose transport or metabolism.

Acknowledgements This work was supported by the Wellcome Trust (grant 075049/Z/04/Z).

Open Access This article is distributed under the terms of the Creative Commons Attribution Noncommercial License which permits any noncommercial use, distribution, and reproduction in any medium, provided the original author(s) and source are credited.

\section{References}

1. Adson A, Raub TJ, Burton PS, Barsuhn CL, Hilgers AR, Audus KL, Ho NF (1994) Quantitative approaches to delineate paracellular diffusion in cultured epithelial cell monolayers. J Pharm Sci 83:1529-1536

2. Ashcroft SJ, Nino S (1978) Effects of phloretin and dextran-linked phloretin on pancreatic islet metabolism and insulin release. Biochim Biophys Acta 538:334-342

3. Baker EH, Clark N, Brennan AL, Fisher DA, Gyi KM, Hodson ME, Philips BJ, Baines DL, Wood DM (2007) Hyperglycemia and cystic fibrosis alter respiratory fluid glucose concentrations estimated by breath condensate analysis. J Appl Physiol 102:1969-1975 
4. Bals R, Beisswenger C, Blouquit S, Chinet $\mathrm{T}$ (2004) Isolation and air-liquid interface culture of human large airway and bronchiolar epithelial cells. J Cyst Fibros 3(Suppl 2):49-51

5. Barker PM, Boyd CA, Ramsden CA, Strang LB, Walters DV (1989) Pulmonary glucose transport in the fetal sheep. J Physiol 409:15-27

6. Bassett DJ, Fisher AB (1976) Metabolic response to carbon monoxide by isolated rat lungs. Am J Physiol 230:658-663

7. Bassett DJ, Fisher AB, Rabinowitz JL (1974) Effect of hypoxia on incorporation of glucose carbons into lipids by isolated rat lung. Am J Physiol 227:1103-1108

8. Blouquit S, Morel H, Hinnrasky J, Naline E, Puchelle E, Chinet T (2002) Characterization of ion and fluid transport in human bronchioles. Am J Respir Cell Mol Biol 27:503-510

9. Boucher RC, Cotton CU, Gatzy JT, Knowles MR, Yankaskas JR (1988) Evidence for reduced $\mathrm{Cl}-$ and increased $\mathrm{Na}+$ permeability in cystic fibrosis human primary cell cultures. J Physiol 405:77-103

10. Carson JL, Collier AM, Gambling TM, Knowles MR, Boucher RC (1990) Ultrastructure of airway epithelial cell membranes among patients with cystic fibrosis. Hum Pathol 21:640-647

11. Chan TB, Arm JP, Anderson J, Eiser NM (1988) Pulmonary epithelial permeability in bronchiectasis. Br J Dis Chest 82:56-63

12. D'Souza VM, Shertzer HG, Menon AG, Pauletti GM (2003) High glucose concentration in isotonic media alters caco-2 cell permeability. AAPS PharmSci 5:E24

13. Deuticke B (1982) Monocarboxylate transport in erythrocytes. J Membr Biol 70:89-103

14. Dimmer KS, Friedrich B, Lang F, Deitmer JW, Broer S (2000) The low-affinity monocarboxylate transporter MCT4 is adapted to the export of lactate in highly glycolytic cells. Biochem J 350(Pt 1):219-227

15. Dunbar LA, Caplan MJ (2000) The cell biology of ion pumps: sorting and regulation. Eur J Cell Biol 79:557-563

16. Ferraris RP, Yasharpour S, Lloyd KC, Mirzayan R, Diamond JM (1990) Luminal glucose concentrations in the gut under normal conditions. Am J Physiol 259:G822-G837

17. Halestrap AP, Meredith D (2004) The SLC16 gene family-from monocarboxylate transporters (MCTs) to aromatic amino acid transporters and beyond. Pflugers Arch 447:619-628

18. Hermanns MI, Unger RE, Kehe K, Peters K, Kirkpatrick CJ (2004) Lung epithelial cell lines in coculture with human pulmonary microvascular endothelial cells: development of an alveolo-capillary barrier in vitro. Lab Invest 84:736-752

19. Kalsi KK, Baker EH, Medina RA, Rice S, Wood DM, Ratoff JC, Philips BJ, Baines DL (2008) Apical and basolateral localisation of GLUT2 transporters in human lung epithelial cells. Pflugers Arch 456:991-1003

20. Katz J, Dunn A, Chenoweth M, Golden S (1974) Determination of synthesis, recycling and body mass of glucose in rats and rabbits in vivo 3H- and 14C-labelled glucose. Biochem J 142:171-183

21. Keller DM, Lotspeich WD (1956) A study of some effects of phlorizon on the metabolism of kidney tissue in vitro. J Biol Chem 222:843-853

22. Kirat D, Masuoka J, Hayashi H, Iwano H, Yokota H, Taniyama H, Kato S (2006) Monocarboxylate transporter 1 (MCT1) plays a direct role in short-chain fatty acids absorption in caprine rumen. $\mathrm{J}$ Physiol 576:635-647

23. Koukourakis MI, Giatromanolaki A, Bougioukas G, Sivridis E (2007) Lung cancer: a comparative study of metabolism related protein expression in cancer cells and tumor associated stroma. Cancer Biol Ther 6:1476-1479

24. Ladanyi M, Antonescu CR, Drobnjak M, Baren A, Lui MY, Golde DW, Cordon-Cardo C (2002) The precrystalline cytoplasmic granules of alveolar soft part sarcoma contain monocarboxylate transporter 1 and CD147. Am J Pathol 160:1215-1221

25. Lazrak A, Matalon S (2003) cAMP-induced changes of apical membrane potentials of confluent H441 monolayers. Am J Physiol Lung Cell Mol Physiol 285:L443-L450

26. Mullin JM, Fluk L, Kleinzeller A (1986) Basal-lateral transport and transcellular flux of methyl alpha-D-glucoside across LLCPK1 renal epithelial cells. Biochim Biophys Acta 885:233-239

27. Pappenheimer JR (1953) Passage of molecules through capillary wals. Physiol Rev 33:387-423

28. Pappenheimer JR (1993) On the coupling of membrane digestion with intestinal absorption of sugars and amino acids. Am J Physiol 265:G409-G417

29. Pappenheimer JR, Renkin EM, Borrero LM (1951) Filtration, diffusion and molecular sieving through peripheral capillary membranes; a contribution to the pore theory of capillary permeability. Am J Physiol 167:13-46

30. Philips BJ, Redman J, Brennan A, Wood D, Holliman R, Baines D, Baker EH (2005) Glucose in bronchial aspirates increases the risk of respiratory MRSA in intubated patients. Thorax 60:761-764

31. Russell RW, Young JW (1990) A review of metabolism of labeled glucoses for use in measuring glucose recycling. J Dairy Sci 73:1005-1016

32. Saumon G, Martet G (1996) Effect of changes in paracellular permeability on airspace liquid clearance: role of glucose transport. Am J Physiol 270:L191-L198

33. Saumon G, Martet G, Loiseau P (1996) Glucose transport and equilibrium across alveolar-airway barrier of rat. Am J Physiol 270:L183-L190

34. Schneeberger EE, Walters DV, Olver RE (1978) Development of intercellular junctions in the pulmonary epithelium of the foetal lamb. J Cell Sci 32:307-324

35. Shepherd EJ, Helliwell PA, Mace OJ, Morgan EL, Patel N, Kellett GL (2004) Stress and glucocorticoid inhibit apical GLUT2trafficking and intestinal glucose absorption in rat small intestine. J Physiol 560:281-290

36. Thomas CP, Campbell JR, Wright PJ, Husted RF (2004) cAMPstimulated $\mathrm{Na}+$ transport in H441 distal lung epithelial cells: role of PKA, phosphatidylinositol 3-kinase, and sgk1. Am J Physiol Lung Cell Mol Physiol 287:L843-L851

37. Tomiya N, Suzuki T, Awaya J, Mizuno K, Matsubara A, Nakano K, Kurono M (1992) Determination of monosaccharides and sugar alcohols in tissues from diabetic rats by high-performance liquid chromatography with pulsed amperometric detection. Anal Biochem 206:98-104

38. Wangensteen D, Bartlett M (1984) D- and L-glucose transport across the pulmonary epithelium. J Appl Physiol 57:1722-1730

39. Winkler BS, Starnes CA, Sauer MW, Firouzgan Z, Chen SC (2004) Cultured retinal neuronal cells and Muller cells both show net production of lactate. Neurochem Int 45:311-320

40. Wood DM, Brennan AL, Philips BJ, Baker EH (2004) Effect of hyperglycaemia on glucose concentration of human nasal secretions. Clin Sci (Lond) 106:527-533

41. Woollhead AM, Scott JW, Hardie DG, Baines DL (2005) Phenformin and 5-aminoimidazole-4-carboxamide-1-beta-D-ribofuranoside (AICAR) activation of AMP-activated protein kinase inhibits transepithelial $\mathrm{Na}+$ transport across $\mathrm{H} 441$ lung cells. J Physiol 566:781-792

42. Woollhead AM, Sivagnanasundaram J, Kalsi KK, Pucovsky V, Pellatt LJ, Scott JW, Mustard KJ, Hardie DG, Baines DL (2007) Pharmacological activators of AMP-activated protein kinase have different effects on $\mathrm{Na}+$ transport processes across human lung epithelial cells. Br J Pharmacol 151:1204-1215 